seventeen ground generators located between Florida and New York. The object of the trials was to determine whether cloud-seeding could change the intensity or direction of developing storms. Thirtyseven meteorological situations were selected, and seeding was carried out on eighteen occasions, the seeded and non-seeded cases being selected on a random basis and then paired. The non-seeding occasions were used as control situations. During the first period of operations, three aircraft flew along parallel tracks a hundred miles apart each dispensing 1,000 lb. of crushed 'dry ice' at the rate of $1 \mathrm{Ib} . / \mathrm{mile}$; during the second period, 2,500 lb. was dispensed at $5 \mathrm{lb}$./mile along 500-mile tracks. Tho silver iodide generators were operated for twelvehour periods. In trying to detect possible effects caused by the seeding, particular attention was paid to pressure changes; secondary factors were precipitation, cloud formation and wind direction. The report adds that the trials showed no evidence that statistically significant large-scale effects were caused by the seeding.

\section{Folia Biologica: New Czechoslovak Journal}

THE first number of a new bi-monthly journal, Folia Biologica, which is the international edition of Československá Biologie, has recently appeared, published in Prague (from 'Artia', Smečky 30, Praha 2 ; $60 \mathrm{Kčs}$. a year, or $10 \mathrm{Kčs}$. an issue). The first article, on the significance of phylogenetic kinship in immunological approximation during embryogenesis, by M. Hašek and T. Hraba, is written in English and has a summary in Russian. The authors experimentally connected the extra-embryonic circulatory systems of duck and hen chicks, turkey and hen chicks, and pheasant and hen chicks, and studied the immunological results. The second article, on the growth of tumour cells in synthetic media, by M. Rychlíková and H. Keilová, is written in Russian with a summary in English and is illustrated by photographs. Two other articles are also in Russian with summaries in English: the vitality of cell fragments of yeasts - (1) plasmatic droplets of yeasts, by $\mathrm{O}$. Nečas ; and a method for evaluating the effect of ionizing radiation on micro-organisms (the hypotrichous ciliate protozoon Tetrahymena gelei), by A. Lengerová. Three articles are in Russian with summaries in German: the splitting of starch by the enzymatic complex of soils (J. Drobník); the relationship of enzymatic inversion in the soil to some microbiological tests (J. Drobník and $J$. Seifert); and the composition and changes in humus in some forest soils (Z. Ambrož). The number ends with a note in Russian, with a summary in English, on double-staining with acid stains in plant tissue, by I. Hršel.

\section{Science Tools: New Swedish Journal}

The firm of LKB-Produkter Fabriksaktiebolag, Stockholm, has begun issuing a new journal, Science Tools, which is published in English, about once every three months, and is intended to be a link between the instrument manufacturer and the laboratory research worker. The journal contains articles by well-known seientific workers dealing with modern equipment used in physical chemistry and nuclear science. In the first three numbers which have already appeared there are a number of articles of wide appeal : for example, E. Valmet and H. Svensson, on problems connected with paper electrophoresis;
H. Svensson and B. Olhagen, on electrophoresis of serum and plasma in free solution without prior dialysis; and L. Hagdahl, on the use of coupled columns in chromatography. The journal is issued free to laboratory workers, who if they work in Great Britain should apply in the first place to Hudes Merchandizing Corporation, Ltd., Charter House, 52 Gloucester Place, London, W.1.

\section{Early Carboniferous Floras}

A Monograph by W. J. Jongmans on "The Carboniferous Flora of Peru" (Bull. Brit. Mus. (Nat. Hist.), Geology, 2, No. 5 ; pp. $36+10$ plates ; 1954 ; 15s.) emphasizes anew the wide distribution of floras of comparatively uniform aspect in the early Carboniferous in contrast with the differentiation of wellmarked floral provinces in later Carboniferous times. Jongmans confirms as Lower Carboniferous the age of certain floras on the west coast of Peru which have sometimes been assigned to the later Carboniferous : he uses new collections of these compression floras to corroborate earlier results of other workers. Among the genera represented are Rhacopteris, Triphyllopteris, Cyclostigma and Lepidodendropsis; and a critical review is given of the distribution of the latter little-known genus, of which two new species are described. The general aspect of the Peruvian floras is similar to that of RhacopterisLepidodendropsis floras of other Lower Carboniferous localities. Lepidodendropsis is occasionally absent, as in Australia. from the Rhacopteris floras, and also occurs sometimes in strata usually assigned to the Upper Devonian, as in the Donetz basin. Indeed, Jongmans suggests that the Rhacopteris-Lepidoden. dropsis floras may represent a transition between Archaeopteris-Cyclostigma floras of the true Devonian and later floras of the Mississippian.

The difficulty of drawing any clear-cut line between Upper Devonian and Lower Carboniferous with respect to the plants has recently been further illustrated by 'transition' floras from rich collections of petrificd plants in the Devonian-Mississippian black shales of the Upper New Albany formation of Kentucky, Tennessee and Indiana. These plants comprise some twenty-nine genera, many representing stem and leaf axes, which have been reviewed and redescribed by A. T. Cross and J. H. Hoskins (J. Paleo., 25, No. 6, 713 (1951), and C.R. 3me Cong. Avanc. Études Stratigr. Carbonifère, 1, 113 (1952) (Heorlen)). So far, no connexions between species of the compression floras and the petrified floras have been demonstrated, though the circumstances of their distribution suggest that some relationships may exist; but further evidence may well be forthcoming, for example, from the investigation of such floras as those described by Walton from the base of the Lower Carboniferous in the Kilpatrick Hills in Scotland, where the plant-remains are part petrified and part compressed. Jongmans's review focuses fresh interest on those horizons where critical stages in the evolution of the rich later Carboniferous floras, and in particular of the seed plants, may be followed up.

\section{Rain and Plant Dispersal Mechanisms}

H. J. BrodıE (Canad. J. Bot., 33, 2, 156 ; 1955) has given an account of a number of seed dispersal mechanisms of the 'springboard' type which are operated by raindrops. Most of the older accounts of seed dispersal in such genera as Salvia leave the impression that almost any kind of blow will set off 